\section{En krigers bekjennelser}

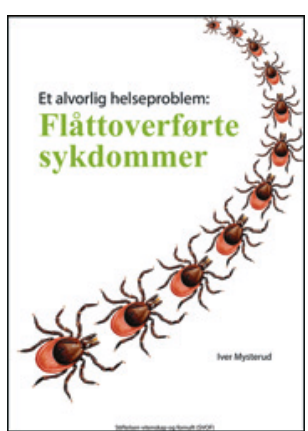

Iver Mysterud

\section{Flåttoverførte sykdommer}

Et alvorlig helseproblem. $295 \mathrm{~s}$, tab, ill. Jar: Stiftelsen vitenskap og fornuft (SVOF), 2014. Pris NOK 295

ISBN 978-82-999591-0-0

Denne boken er det vanskelig å anmelde i et medisinsk fagtidsskrift. La det være klart: Dette er ikke en bok om flåttoverførte sykdommer. På 18 av bokens 295 sider nevnes riktignok hvordan andre organismer kan gi koinfeksjon ved borreliose, men resten handler om det forfatteren kaller «borreliakrigen», og hvordan borreliabehandling blir når krigen mot skolemedisin og norsk og nordamerikansk byråkrati snart er over.

Diagnostisk går krigen på to plan. Det ene gjelder innføringen av lymfocyttransformasjonstesten Elispot og CD57-måling. Det angis at disse «ikke er borreliaspesifikke og heller ikke diagnostiske». Likevel roses leger som bruker testene som om de er nettopp det. På det andre planet omtales mikroskopi av blodutstryk som et nytt diagnostisk gjennombrudd, hvilket er feil. Metoden har vært brukt for påvisning av særlig Borrelia recurrentis og Borrelia duttoni siden Otto Obermeiers første demonstrasjon i Virchows laboratorium i Berlin og senere publikasjon i Centralblatt für die medizinischen Wissenschaften 1. mars 1873. For tiden er metoden lite aktuell i Norge, men altså ikke ny. Metoden er meget nyttig ved septisk forløpende tilbakefallsfeber, men uegnet når bakteriekonsentrasjonen synker mellom feberanfallene. Av samme årsak har den ikke plass i rutinediagnostikken av Borrelia burgdorferi.

«Borreliakrigen» handler ellers om retten til langvarig antibiotikabehandling når kort behandling ikke helbreder. Av to referanser som bekrefter effekt av slik forlengelse, er den ene en personlig meddelelse fra Ottar Longva, og den andre er en lite autoritativ studie. Månedslange antibiotikakurer med usikker effekt er særlig utfordrende i en tid da all medisinsk virksomhet trues av omfattende antibiotikaresistens. Skjønt langvarig - i boken roses også leger som avstår fra antibiotika ved påvist tidlig borreliose «når behandling ikke er nødvendig».

Over 203 sider som omhandler støttebehandling, utfordres Hippokrates formaning: «Forvold framfor alt ikke skade.» Her frembys plantemedisinske og andre terapier inntil det uoversiktlige, og det sies at tilfredsstillende studier av effekt og bivirkninger ikke er gjennomført. I avgiftningsøyemed anbefales bl.a. daglig inntak av inntil $18 \mathrm{~g}$ salt og like stor mengder vitamin $\mathrm{C}$ under behandlingen, som kan vare lenge. Vi leser om elektromedisinske apparater som kan kjøpes til eget bruk, om biopati, akupunktur og biofotonterapi. Forfatteren presenterer sin filosofi om tilfriskning $i$ et videre perspektiv og har ellers en presentasjon over enheter som tilbyr alternativ behandling.

Dette er altså et konglomerat av kostbare og potensielt farlige påfunn uten dokumentert effekt. Det er en tragedie at slik lesning representerer håp for tusenvis $\mathrm{av}$ invalidiserte nordmenn. Hva er det ved vårt helsevesen som mangler den omsorgen de finner her?

Boken begynte imidlertid godt. Tilegnelsen til vår internasjonalt kjente borreliaprofil, Øystein Brorson, varmer.

\section{Uforløst om smittsomme mikrober}

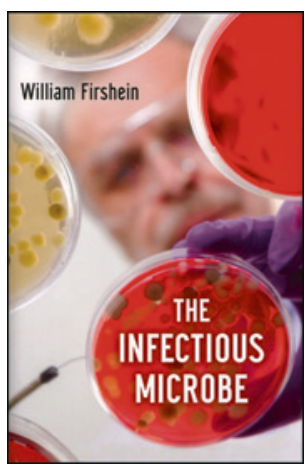

William Firshein

The infectious microbe

160 s, tab, ill. Oxford: Oxford University Press, 2014. Pris GBP 20

ISBN 978-0-19-932961-8

Tittelen lover mer enn den holder, for forfatteren gjør ikke noe forsøk på å skille infeksiøse fra ikke-infeksiøse mikrober. Han gir heller ikke et anslag av hvor mange typer smittestoffer som regelmessig smitter mennesket. Av de store gruppene ramser han opp bakterier, virus og sopp, men neglisjerer nærmest parasitter. I mangt er dette derfor en uforløst bok om mikrober.

Og like uforløst er boken i forhold til målgruppen - den interesserte allmennhet. For forfatteren har neppe en klar forestilling om den allmenne lesers kunnskapsnivå, og han har heller ikke tatt deres perspektiv som utgangspunkt for sin fremstilling.

Boken er inndelt i sju kapitler: En introduksjon til den smittsomme mikrobe, Fundamentale biologiske og kjemiske begreper som kan bidra til å forstå patogenisitet, Mikrobiologiens historie, Nye og tilbakevendende sykdommer, Kasuistikker, Biofilmer og til slutt Biologisk terrorisme. For alle kapitlene gjelder det at forfatteren har tatt for seg de aspektene ved tematikken han synes er mest interessant, og derfor virker da også fremstillingen relativt usystematisk.

Men disse innvendingene til tross - The infectious microbe er en god bok for den som kjenner noe til mikrobiologi fra før, og som dessuten ønsker en kort og konsis repetisjon av mikrobenes molekylærbiologi. Forfatteren har vært professor i biologi i nærmere 50 år og har undervist ulike typer studenter enda lenger. Og derfor preges boken av en rekke figurer som sammenfatter kompliserte funksjoner på en god og forståelig måte.

\section{Elling Ulvestad}

Avdelingssjef, Mikrobiologisk avdeling

Haukeland universitetssykehus 